As diversity increases in the general population, U.S. colleges and universities are struggling to maintain campus diversity in the context of legislative elimination of affirmative action in admissions.

\title{
The History and Impact of State Initiatives to Eliminate Affirmative Action
}

\author{
Susan W. Kaufmann
}

Since 1995, efforts to prohibit affirmative action have intensified, perhaps most strikingly in higher education. In 1996, California voters adopted Proposition 209 (Prop. 209), an amendment to the state constitution that banned both discrimination and affirmative action programs that give preferences to groups or individuals based on their race, gender, color, ethnicity, or national origin for public employment, education, or contracting purposes. Also in 1996, the Fifth Circuit Court of Appeals issued a decision, Hopwood v. Texas, ending affirmative action in private and public college and university admissions in Texas, Louisiana, and Mississippi. Late in 1997, Gratz v. Bollinger and Grutter v. Bollinger challenged the use of affirmative action in undergraduate and law school admissions, respectively. In 1998, Washington voters passed Initiative 200 (I-200), nearly identical to Prop. 209 except a state law, not a constitutional amendment. In 1999, Florida Governor Jeb Bush preissued an executive order ending consideration of race and ethnicity in public college and university admissions, public employment, and government contracting.

In 2003, the U.S. Supreme Court, in both Grutter v. Bollinger and Gratz v. Bollinger, affirmed the validity of race-based affirmative action in college admissions. During a holistic review of each applicant's strengths and potential contributions to the class, the Court concluded, race or ethnicity could be considered as one factor among many others, if it is not done

\section{(W)WILEY


mechanistically. A variety of evidence persuaded the Supreme Court to uphold affirmative action:

- Students of all races who live and learn among diverse peers in both formal classroom and informal settings that challenge them to absorb and respond to new points of view develop the capacity for more original and critical thinking. They also develop "democracy skills, including greater tolerance for differences as a normal part of life" (Gurin, 1997; Gurin, Dey, Hurtado, and Gurin, 2002, p. 330).

- "Race unfortunately still matters" in American life, as evidenced by continuing disparities ("Brief," 2003, p. 23).

- "The path to leadership must be visibly open to talented and qualified individuals of every race and ethnicity" ("Brief," 2003, p. 23).

- Over three hundred organizations filed amicus (friend of the court) briefs on behalf of the University of Michigan, the largest number ever filed in a case before the Supreme Court.

The Court found particularly persuasive the military's amicus brief, which stated that the armed forces could not assemble a diverse officer corps without employing affirmative action in the military academies, and it could not lead effectively_or even safely-if officers did not reflect the diversity of the enlistees, making affirmative action a matter of national security ("Brief," 2003, p. 22). The brief filed by sixty-five Fortune 500 businesses similarly emphasized the centrality of affirmative action to their core values and operations, asserting that "an educational environment that ensures participation by diverse people, viewpoints and ideas will help produce the most talented workforce" ("Brief," 2003, pp. 1-2).

Two weeks after the Supreme Court issued its decisions in the Grutter and Gratz cases, Gratz plaintiff Jennifer Gratz and Ward Connerly launched a Michigan ballot initiative campaign. Called the Michigan Civil Rights Initiative, or Proposal 2, the measure-a constitutional amendment virtually identical to Prop. 209-passed in 2006. Following that victory, Connerly and Gratz announced that they are exploring the feasibility of mounting campaigns in several western states. Ironically, efforts to end affirmative action are occurring during a period of rapid demographic change in the United States. U.S. Census Bureau data for 2005 show that non-Hispanic whites are now a minority in four states, including Texas and California.

\section{Impact of Prop. 209 on Higher Education in California}

Passing a ballot initiative is only the first step in determining its policy implications; often courts must interpret the language so that policy decisions can be made. In September 1997, California Governor Pete Wilson held a press conference to announce a list of over thirty "offending statutes" that he believed violated Prop. 209 and called on the legislature to repeal or 
amend them (California Governor's Office, 1997). These statutes included precollege outreach and preparation programs, scholarships and fellowships, and professional training programs. Subsequently, references to race and gender in those California programs have been either eliminated or replaced by socioeconomic status, a highly problematic proxy for race since not all underrepresented minorities have low incomes and even those who are affluent may still experience bias and discrimination.

\section{Impact of Prop. 209 on University Enrollments at the University of California}

According to Richard Atkinson, former president of the University of California system, "In 1995, before Proposition 209 took effect, underrepresented minority students accounted for 38 percent of California high school graduates and 21 percent of entering University of California freshmen, a difference of 17 percent. In 2004, they made up 45 percent of high school graduates but had fallen to 18 percent of incoming UC freshmen, a difference of 27 percent" (Atkinson and Pelfrey, 2005, p. 8). Enrollment decreases at UC Berkeley and UCLA have been even steeper. Atkinson continues, "In 1995, UC Berkeley and UCLA together enrolled a total of 469 AfricanAmerican women and men in a combined freshman class of 7,100. In 2004, the number was 218 , out of a combined freshman class of 7,350. AfricanAmerican men, in particular, are virtually disappearing from our campuses. UCLA and Berkeley together admitted 83 African-American men in 2004" (p. 8). In 2006, UCLA, which is located in the county with the second largest African American population in the United States ("Struggling," 2006), enrolled the smallest number of entering African American freshmen "since at least 1973" (Trounson, 2006, p. 1).

The percentage of Latino students attending the University of California also dropped following passage of Prop. 209. Although the trend reversed in 2001 and the percentage of Latino students admitted to the University of California system now exceeds pre-Prop. 209 levels, it does so in the context of a rapidly increasing Latino population in the state of California. The percentage of Latinos at Berkeley and UCLA is still significantly lower than in 1997. The percentage of Native American students enrolled in the UC system dropped 38 percent from 1997 to 2006 and has not been increasing (University of California, 2006).

Low and declining enrollments of underrepresented minority students at the University of California follow several changes resulting from Prop. 209: the end of affirmative action (Birgeneau, 2005a; 2005b); elimination of targeted outreach programs (Laird, 2005); the perception, as their numbers dwindle, that the university is unwelcoming to underrepresented minorities (Birgeneau, 2005a); and a growing tendency for underrepresented students with strong academic records to enroll elsewhere (Laird, 2005). These Prop. 209-related trends are occurring in the context of 
"disparities in [K-12] educational opportunity for underrepresented students," including access to Advanced Placement and honors curricula (Contreras, 2005); reduction or elimination of state funding for raceneutral college preparatory and outreach programs (Torres, 2004); increasing competition and selectivity in University of California admissions as applications rise faster than capacity (Laird, 2005; Rendón, Novack, and Dowell, 2005); and rising tuition (Laird, 2005) and decreasing need-based financial aid (Kidder, Serrano, and Acheta, 2004). The fact that UC Berkeley typically receives more than twice as many applications from students with grades above 4.0 as it has places in the freshman class is one measure of the intense competition for admission (Laird, 2005).

The University of California has tried many race-neutral means of increasing enrollments of underrepresented students since affirmative action became illegal (Atkinson and Pelfrey, 2005, pp. 6-8):

- Outreach programs to high schools that send few students to the University of California

- Emphasis on achievement rather than aptitude tests

- Comprehensive review of applications, including consideration of obstacles students have overcome and the use they have made of opportunities

- Eligibility under the Local Context Project, a percentage plan making students graduating in the top 4 percent of each high school eligible for enrollment at one of the University of California campuses, provided they have taken a series of required courses

- Guaranteed admission to a University of California campus for community college transfer students meeting course and grade requirements

According to Atkinson and Pelfrey (2005), "Despite enormous efforts, we have failed badly to achieve the goal of a student body that encompasses California's diverse population. ... Any state tempted to emulate the example of California should think long and hard about the consequences" (p. 10). For UC Berkeley Chancellor Robert Birgeneau, diversity is the foundation of effective education: "We are . . missing out on exceptional African American, Latino and Native American students who can not only succeed here, but whose participation can improve the education the university offers all its students. . . The single most important skill that a 21 st century student must master is 'intercultural competence'-the ability ... to navigate successfully in today's globalized society" (2005a).

\section{Impact of Prop. 209 on University Enrollments at the California State University}

Enrollments of African Americans and Native Americans have also fallen at the California State University as a percentage of total enrollments since the passage of Prop. 209. In 1996 and 1997, African American enrollment 
peaked at 7.3 percent of the total. Beginning in 1998, it declined each year, reaching 6.5 percent in 2004, an 11 percent decrease. Native American enrollment peaked at 1.2 percent from 1994 to 1996 and dropped steadily to 0.8 percent in 2004, a 25 percent decrease (Schreck, 2006). Rapidly rising enrollment pressure from the children of the baby boomers means that admission to California State campuses is becoming increasingly competitive and beginning to be affected by many of the same forces shaping University of California enrollments (Rendón, Novack, and Dowell, 2005).

\section{Percentage Plans}

California, Texas, and Florida have all mandated "percentage plans" to replace affirmative action. Those plans require that students who rank in a specified top percentage of their high school graduating class be admitted to a campus in the state university system. Although the plans have had limited success in broadening access, typically by rural students (Laird, 2005), they have not generally succeeded in maintaining the level of student body diversity achieved with affirmative action (Tienda and others, 2003), particularly on the most competitive campuses (Horn and Flores, 2003). For one thing, many students eligible under percentage plans would already have been eligible under existing admissions criteria (Laird, 2005; Horn and Flores, 2003). In addition, such plans have required massive and expensive new outreach programs, along with large infusions of scholarship support (Tienda and others, 2003), to encourage top-performing students in schools that rarely send students to universities to apply and attend. Furthermore, the plans' success in achieving diversity depends largely on existing segregation in the states' school systems (Laird, 2005). Following the Grutter decision, the University of Texas at Austin has reinstated affirmative action alongside its percentage plan (Laird, 2005).

\section{Conclusion}

Eliminating affirmative action in California has led to a number of consequences in the educational realm: declining percentages of underrepresented minorities enrolled at the University of California, especially at flagship institutions, as well as at the California State University; the end of targeted outreach efforts; and the failure of alternative methods, including a percentage plan, to maintain the level of diversity achieved under affirmative action. In addition to the impact of undergraduate student enrollment covered in this chapter, these efforts have also led to significant decreases in graduate and professional school enrollment of underrepresented students, decreases in the hiring of women faculty and faculty of color at the University of California, and the elimination of voluntary school desegregation efforts in some cities, with continuing challenges in others.

As the U.S. Supreme Court noted in Grutter v. Bollinger, students of all races who experience the benefits and challenges of living and learning 
among diverse peers develop the capacity for more original and critical thinking. They also develop the ability to negotiate both difference and commonality within and between groups. Years after graduating, students who have learned to engage effectively with members of other groups in college remain more likely to maintain cross-racial relationships and to live in integrated communities. Such experience is particularly important because most students, particularly whites, grow up in segregated communities and experience diversity for the first time when they go to college (Atkinson and Pelfrey, 2005; Gurin, 1997; Gurin, Dey, Hurtado, and Gurin, 2002). In addition, employers value students educated in highly diverse educational settings because they are better able to integrate different perspectives to solve problems, develop and market products that appeal to a variety of customers, partner with constituencies in the United States and around the world, and discourage discrimination and stereotyping ("Brief," 2003). Since the passage of Prop. 209, opportunities for students in California public universities to learn among peers who reflect the diversity of the state and to derive the benefits of such an education have diminished, particularly the most selective institutions.

Ten years after Prop. 209, its effects continue to unfold. To varying degrees, similar trends have resulted from affirmative action bans in Washington, Florida, and Texas. Now Michigan institutions and policymakers, aware of consequences elsewhere, are searching for ways to preserve diversity within the framework of Proposal 2, while Ward Connerly and Jennifer Gratz are planning a multistate effort to pass additional referendums in the hope that the U.S. Supreme Court will eventually abolish affirmative action.

\section{References}

Atkinson, R., and Pelfrey, A. "Opportunity in a Democratic Society: A National Agenda." Paper prepared for the Third Annual Nancy Cantor Distinguished Lecture on Intellectual Diversity, delivered by Richard C. Atkinson at the University of Michigan, May $18,2005$.

Birgeneau, R. J. “Anti-Bias Law Has Backfired at Berkeley." UC Berkeley Web Feature. Mar. 29, 2005a. http://www.berkeley.edu/news/media/releases/2005/03/29_oped. shtml. Accessed Nov. 28, 2005.

Birgeneau, R. J. "'The System Is Broken': Chancellor Robert J. Birgeneau Discusses Proposition 209 and Its Consequences at UC Berkeley." UC Berkeley Web Feature. Mar. 29, 2005b.http://www.berkeley.edu/news/media/releases/2005/03/29_birgeneau. shtml. Accessed Nov. 28, 2005.

"Brief for Amici Curiae 65 Leading American Businesses in Support of Respondents," In Grutter et al. v. Bollinger et al., 539 U.S. 306 (2003), Feb. 18, 2003.

California Governor's Office. "Wilson Unveils List of 30 Offending Statutes." Press Release 97:331. Sept. 9, 1997. http://aad.english.ucsb.edu/docs/wilson.9-97.html. Accessed May 22, 2007.

Contreras, F. E. "The Reconstruction of Merit Post-Proposition 209." Educational Policy, 2005, 19(2), 371-395. 
Gurin, P. "Expert Report of Patricia Gurin." In The Compelling Need for Diversity in Higher Education. Ann Arbor: University of Michigan, 1997. http://www.vpcomm. umich.edu/admissions/legal/expert/gurintoc.html. Accessed May 22, 2007.

Gurin, P., Dey, E., Hurtado, S., and Gurin, G. "Diversity and Higher Education: Theory and Impact on Educational Outcomes." Harvard Educational Review, 2002, 72(3), 330-366.

Horn, C., and Flores, S. Percent Plans in College Admissions: A Comparative Analysis of Three States' Experience. Cambridge, Mass.: Civil Rights Project, Harvard University, 2003.

Kidder, W., Serrano, S. K., and Acheta, A. N. "In California, a Misguided Battle over Race." Chronicle of Higher Education, 2004, 50(37), p. B16. http://chronicle.com/prm/ weekly/v50/i37/37b01601.htm. Accessed May 22, 2007.

Laird, B. The Case for Affirmative Action in University Admissions. Berkeley, Calif.: Bay Tree, 2005.

Rendón, L. I., Novack, V., and Dowell, D. "Testing Race-Neutral Admission Models: Lessons from California State University-Long Beach.” Review of Higher Education, 2005, 28(2), 221-243.

Schreck, A. "Changing Faces of California State University Faculty and Students: A Summary of Data on the Racial/Ethnic and Gender Diversity in the CSU." Paper presented at the CFA Equity Conference 2006: Building Power Through Diversity and Activism, Mar. 2006.

"Struggling to Keep Black Students." Inside Higher Ed, June 6, 2006, citing Darnell Hunt, head of the Ralph Bunche Center for African American Studies, UCLA. http://insidehighered.com/layout/set/print/news/2006/06/06/black. Accessed June 6, 2006.

Tienda, M., Leicht, K. T., Sullivan, T., Maltese, M., and Lloyd, K. "Closing the Gap? Admissions and Enrollments at the Texas Public Flagships Before and After Affirmative Action." Working Paper no. 2003-01. Princeton, N.J.: Office of Population Research, Princeton University, 2003.

Torres, C. "Eliminating Outreach at the University of California: Program Contributions and the Consequences of Their Reductions." Los Angeles: Tomas Rivera Policy Institute, University of Southern California, 2004.

Trounson, R. "A Startling Statistic at UCLA." Los Angeles Times, June 3, 2006, p. 1. http://www.latimes.com/news/printedition/front/la-me-ucla3jun03. Accessed June 5, 2006.

University of California. "Table 2. Distribution of Statement of Intent to Register (SIRs) for Admitted Freshmen, Fall 1997 Through 2006." May 31, 2006. http://www.ucop. edu/news/factsheets/2006/froshsirs_table2.pdf. Accessed May 22, 2007.

SUSAN W. KAUFMANN is the associate director for advocacy of the University of Michigan Center for the Education of Women. 